\title{
An evolution of Medical News of North Caucasus
}

We are happy to introduce you to the English version of the Medical News of North Caucasus. This is due to the need of presenting the numerous research outcomes to a wide English-speaking audience.

Since its first release in 2006 this journal has been aiming not only at joining together the cutting medical thoughts, yet also to steer the activities carried out by those involved in the fundamental and clinical research covering the widest range of issues within the field of Medicine.

In these years, the Medical News of North Caucasus has never stooped in its development, and each of the articles published now has an individual digital object identifier (DOI), which contributes greatly to the data exchange among Englishspeaking scholars. In 2014 the Medical News of North Caucasus has entered the bibliographic database of Scopus.

It should be noted that all the issues of the Medical News of North Caucasus are available online at http://medvestnik.stgmu.ru. The articles that are part of the journal undergo multi-level review, while all the data presented meet the criteria of the evidence-based medicine, and the Editorial Board shall publish the Medical News of North Caucasus further on.

Professor A. V. Yagoda

Editor-in-chief of the Medical News

of North Caucasus

Professor S. V. Minaev

Research editor of the Medical

News of North Caucasus

\section{Настоящее и буАущее журнала "Меаицинского вестника Северного Кавказа"}

Вашему вниманию предлагается номер журнала «Медицинский вестник Северного Кавказа» на английском языке. Выход данного варианта журнала продиктован необходимостью представления результатов выполненных исследований широкой англоязычной аудитории.

С первого выхода в 2006 году журнал стремился не только объединить передовую медицинскую мысль, но и скоординировать сотрудничество людей, занимающихся фундаментальными и клиническими исследованиями в разных сферах медицины.

За время своего существования журнал «Медицинский вестник Северного Кавказа» постоянно развивался. В настоящее время каждая из выходящих статей имеет персо-

Главный редактор журнала

«Медицинский вестник Северного Кавказа», профессор А. В. Ягода

Научный редактор журнала

«Медицинский вестник Северного Кавказа», профессор С. В. Минаев нальный идентификатор цифрового объекта DOI, обеспечивающий обмен данными между учёными в англоязычной научной среде. В 2014 года «Медицинский вестник Северного Кавказа» вошел в реферативную базу данных Scopus.

Следует отметить, что все выпуски журнала «Медицинский вестник Северного Кавказа» доступны в Интернете на сайте http://medvestnik. stgmu.ru. Опубликованные в журнале статьи проходят многоуровневую систему рецензирования, представленная в них научная информация соответствует требованиям доказательной медицины.

В планах редколлегии и впредь практиковать подобные выпуски журнала. 